\title{
Features of the Migration Flows in the Regions of the Russian Federation
}

\author{
Andrey Shevyakin* \\ South-Western State University, Kursk, Russian Federation
}

\begin{abstract}
Labor potential is one of the most important factors of functioning of the regional economy, which provides an opportunity for its development. Moreover, the role of labor potential increases with time. If in the past people were considered only as employees, nowadays at period of the development of automation and robotics, more and more attention is paid to creative approach and non-standard thinking. It determines the trend, in which higher and higher requirements are placed on the level of training and education of the labor force in the era of innovative technologies.
\end{abstract}

\section{Introduction}

Development of a modern regional economy is one of the priorities of state and public administration. Economic growth seems to be a key driver of the increase of the level of welfare in society. In turn, productivity of the labor force is directly related to the intensive economic growth of the economy of the regions of the Russian Federation [2, 5, 19].

The process of digitalization is one of the most important attributes and factors of dynamic and effective development in the context of the development of modern society and economy. Modern market economy considers human resources as the factor of production, which, first of all, represents as labor resources. Formation and use of this type of resources is a complex long-term process characterized by a high degree of versatility. One of the most important factors of high-quality expanded reproduction of labor resources is the maintenance of a sufficiently high and competitive standard of living in comparison with other regions $[6,12]$.

\section{Materials and methodology}

In the Russian Federation territorial division is based on a system of subjects. There are also macro-regions that combine the following subjects: Central, North-Western, Southern, North-Caucasian, Volga, Ural, Siberian and Far Eastern. The practice of statistical accounting within the federal districts makes it possible to carry out studies of large territorial formations, minimizing the influence of the features of the development of the regions $[1,3]$.

* Corresponding author : andreas21074@mail.ru 
The number of economically active population in the Russian Federation in 2008 reached 75.7 million people. For the next 10 years, there was a period of slight fluctuations, according to the results of which in recent years there has even been a slight increase and the maximum value of the indicator was recorded in 2015 - more than 76.5 million people. The subsequent reduction and the nature of the demographic structure of society indicate an impending period of decline in the number of economically active population $[16,17,18]$.

For a more detailed analysis of the situation in the regional economy, it is important to conduct a study of the dynamics of the economically active population not only in the country, but also in the regions, in particular, in the federal districts. Figure 1 shows graphs describing the number of economically active population in the Russian Federation by federal districts for the period from 2000 to 2018.

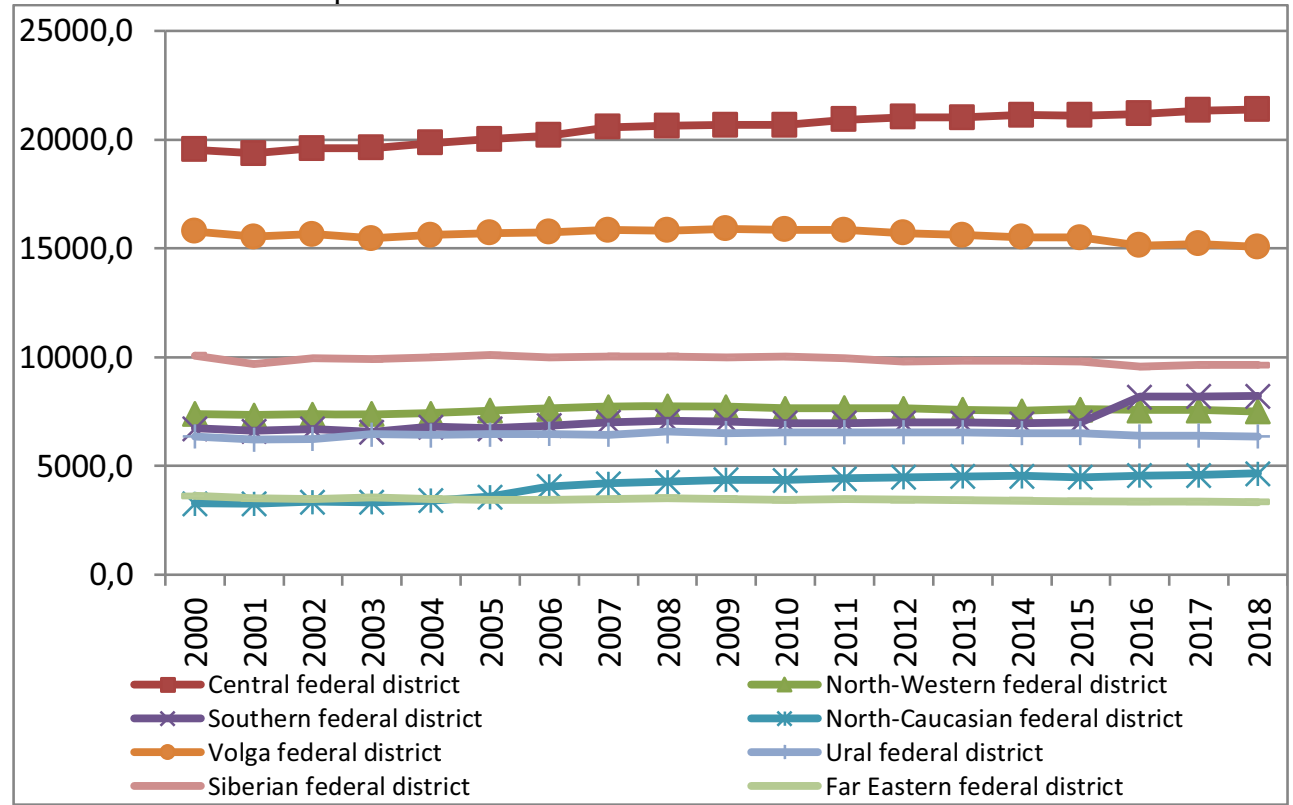

Fig. 1. The number of economically active population in the Russian Federation by federal districts for the period from 2000 to 2018, thousand people

The analysis of figure 1 allows us to conclude that there is a multidirectional dynamics of changes in the number of economically active population in the regions. At the same time, the total number of economically active population has no direct influence for the dynamics of the indicator. The largest increase in absolute terms for the study period was recorded in the Central federal district, where it exceeded 1.8 million people. This federal district mostly correlated with the dynamics of the overall indicator in the country. It's related with the most stable situation in this region and its high impact on the national indicator due to the largest number of economically active population in the Central Federal district. In the Siberian and Volga federal districts, on the contrary, there is a reduction in the number: 474 and 744 thousand people during the study period, correspondingly. The situation in the North-Western federal district is relatively stable, with a trend of slight growth of $1.5 \%$. In the Far Eastern federal district we can highlight a trend for a slight decrease in the number of economically active population - about $9 \%$. The largest growth is observed in the North-Caucasian federal district - about 1.3 million people or $40 \%$. The main reason is the favorable demographic situation, which contributes to a stable increase of the population in the region. The growth of the studied indicator is also observed in the Southern federal district - about 1.5 million people or more than $22 \%$. However, in this 
case the key factor of the noted growth is the entry of new regions into the Southern federal district. If we consider the trend before this event, we can see that in the period from 2000 to 2015 in the Southern federal district there was a slight decrease in the number of economically active population $[8,9]$.

\section{Results}

Migration flows between federal districts depend on the dynamics of economic and social indicators in the regions and, in some cases, determine the intercontinental movement of the population. Table 1 shows the flows and directions of population migration in the Russian Federation between federal districts in 2018.

Table 1. Directions and volumes of the migration of population (urban and rural) in the Russian Federation between federal districts in 2018, thousand people

\begin{tabular}{|c|c|c|c|c|c|c|c|c|c|}
\hline \multirow{2}{*}{$\begin{array}{c}\begin{array}{c}\text { Territory } \\
\text { of arrival }\end{array} \\
\begin{array}{c}\text { Territory } \\
\text { of } \\
\text { departure }\end{array}\end{array}$} & \multirow{2}{*}{$\begin{array}{l}\text { Russian } \\
\text { Federation }\end{array}$} & \multicolumn{8}{|c|}{ In federal districts } \\
\hline & & CFD & NWFD & SFD & NCFD & VFD & UFD & SFD & FEFD \\
\hline $\begin{array}{l}\text { Russian } \\
\text { Federation }\end{array}$ & 4345,9 & 1204,8 & 571,9 & 440,0 & 176,7 & 768,9 & 378,3 & 513,6 & 291,7 \\
\hline CFD & 1076,4 & 816,3 & 59,3 & 54,0 & 24,1 & 68,4 & 18,2 & 20,5 & 15,5 \\
\hline NWFD & 532,7 & 64,5 & 371,2 & 24,3 & 9,6 & 30,4 & 10,6 & 12,6 & 9,6 \\
\hline SFD & 410,6 & 70,0 & 25,7 & 246,6 & 19,6 & 15,4 & 12,5 & 11,2 & 9,5 \\
\hline NCFD & 204,6 & 40,4 & 13,9 & 24,8 & 103,4 & 5,6 & 9,7 & 4,0 & 2,9 \\
\hline VFD & 838,1 & 117,0 & 42,7 & 25,0 & 5,5 & 589,6 & 42,0 & 9,1 & 7,2 \\
\hline UFD & 396,9 & 30,0 & 17,3 & 21,9 & 7,4 & 40,5 & 261,3 & 14,6 & 3,9 \\
\hline SFD & 558,2 & 39,9 & 23,0 & 24,8 & 4,0 & 10,5 & 19,4 & 416,5 & 20,2 \\
\hline FEFD & 328,4 & 26,8 & 18,8 & 18,5 & 3,1 & 8,5 & 4,6 & 25,3 & 222,8 \\
\hline
\end{tabular}

The population of the Central federal district takes the most active part in migration processes. This is caused not only by the high number of its population, but also by higher economic activity of economic entities in comparison with other federal districts. A characteristic feature of migration in the Central federal district is mostly local nature. A lot of people move within the federal district in which they live.

There is a fairly steady movement of the population in the Russian Federation. In particular, the population outflow from the Far Eastern, Siberian, Ural, Volga and NorthCaucasian federal districts. These trends occur despite a fairly active development state policy in these territories, especially in the Far East, Siberian and North-Caucasian. The inflow of the population continues in the Central, North-Western and Southern federal districts. At the same time, there is a significant increase in the volume of migration flows since 2010 , which, on the one hand, may be partly explained by accounting factors, and on the other hand, shows a tendency to increase the mobility of the population.

Research of the impact of the migration factor on the conditions of labor potential in the Russian Federation, based only on the quantitative assessment of the flows within the country, cannot be complete. It is equally important to conduct a more in-depth analysis of migration flows, including movement of the population at the international level [20,21]. 


\section{Discussion}

Labor productivity is one of the fundamental factors of economic development of the economy. At a time when reserves of extensive economic growth are almost exhausted, labor intensification is a key mechanism for additional economic growth. Efficiency and productivity of labor are the primary drivers for economically developed countries, allowing them to provide the highest standard of living for the population. One of the most frequently used indicators that characterize labor productivity in the economy is the gross regional product per capita $[10,11]$.

Graphs describing the dynamics of the gross regional product per capita of the employed population in the regions of the Russian Federation for the period from 2000 to 2017 are presented at figure 2.

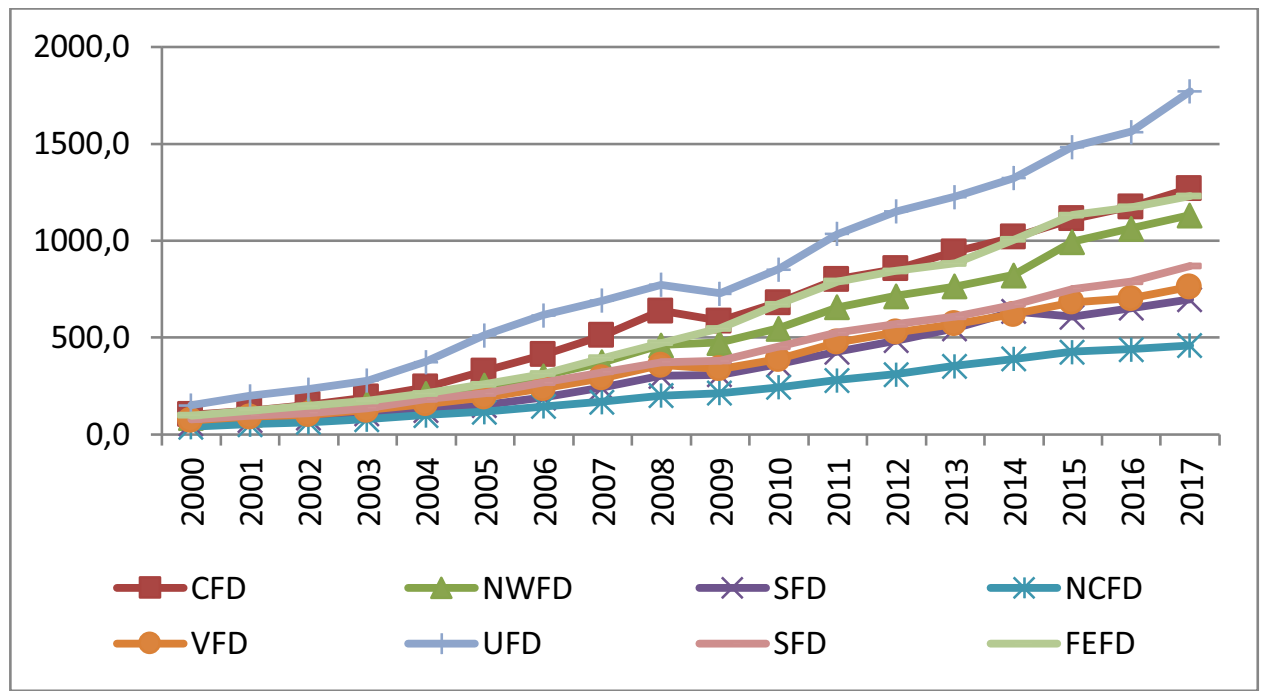

Fig. 2. Gross regional product per capita of the employed population for the full range of organizations in the economy by regions of the Russian Federation for 2000-2017, thousand RUB.

For the study period the highest values of the gross regional product per capita of the employed population were observed in the Ural federal district: 1770.8 thousand rubles in 2017. The minimum value was found in the North-Caucasian federal district $(459.5$ thousand rubles), which is almost 4 times less than the maximum value from the Ural federal district. The remaining federal districts can also be classified into two groups with higher and lower levels of gross regional product per capita:

1) Central, Far Eastern and North-Western federal districts: 1270.7, 1230.7 and 1132.4 thousand rubles, correspondingly in 2017);

2) Siberian, Volga and Southern federal districts: 869.8, 762 and 697.8 thousand rubles, correspondingly in 2017).

The level of differentiation between indicators in regions slowly decrease. of variation in the gross regional product per capita. The coefficient of variation in the gross regional product per capita of the employed population reached a maximum of $48.8 \%$ in 2005 and a minimum of $36.3 \%$ in 2014.

An important role in the formation of the migration flows is played by economic factors, including the level of wages and unemployment. Table 2 shows indicators of unemployment in the federal districts of the Russian Federation in 2018. 
Table 2. Employment and unemployment indicators in the federal districts of the Russian Federation in 2018

\begin{tabular}{|c|c|c|c|c|}
\hline Federal districts & $\begin{array}{c}\text { Migration } \\
\text { balance }\end{array}$ & $\begin{array}{c}\text { Life expectancy at } \\
\text { birth (year, value of } \\
\text { the indicator for the } \\
\text { year) }\end{array}$ & $\begin{array}{c}\text { Unemploy- } \\
\text { ment rate }\end{array}$ & $\begin{array}{c}\text { The percentage of unemployed } \\
\text { people who have been looking } \\
\text { for job for 12 months or more, } \\
\text { in \% }\end{array}$ \\
\hline $\begin{array}{c}\text { Central federal } \\
\text { district }\end{array}$ & 128440 & 74,01 & 2,9 & 25,0 \\
\hline $\begin{array}{c}\text { North-Western } \\
\text { federal district }\end{array}$ & 39171 & 73,3 & 3,9 & 27,8 \\
\hline $\begin{array}{c}\text { Southern federal } \\
\text { district }\end{array}$ & 29376 & 73,54 & 5,6 & 27,1 \\
\hline $\begin{array}{c}\text { North-Caucasian } \\
\text { federal district }\end{array}$ & -27944 & 76,25 & 10,5 & 25,7 \\
\hline $\begin{array}{c}\text { Volga federal } \\
\text { district }\end{array}$ & -69197 & 72,41 & 4,4 & 27,6 \\
\hline $\begin{array}{c}\text { Ural federal } \\
\text { district }\end{array}$ & -18610 & 72,01 & 4,7 & 33,8 \\
\hline $\begin{array}{c}\text { Siberian federal } \\
\text { district }\end{array}$ & -44541 & 70,73 & 6,8 & 34,1 \\
\hline $\begin{array}{c}\text { Far Eastern } \\
\text { federal district }\end{array}$ & -36695 & 70,2 & 5,3 & \\
\hline
\end{tabular}

Data from the table 2 shows that the minimum unemployment rate is typical for the Central federal district: $2.9 \%$ in 2018 . The maximum unemployment rate was recorded in the North-Caucasian federal district: $10.5 \%$ in 2018 . For other federal districts this indicator ranges from $3.9 \%$ to $6.8 \%$. The percentage of unemployed people who have been looking for job for more than 12 months is an important and quite informative indicator. By itself, unemployment is quite mass phenomenon, especially in the context of frictional unemployment. The most negative consequences of unemployment are manifested during its long period: skills are lost, the level of socialization of a person decreases and the risk of criminalization increases. The highest value of this indicator in 2017 was observed in the North-Caucasian federal district (43\%) and in the Siberian federal district (34.9\%). In 2018 maximum value was found in the Far Eastern federal district $(34.1 \%)$. In the NorthCaucasian federal district established a positive dynamics: value of the indicator in the 2018 decreased for 12.2 p.p.

The analysis of the migration balance shows that the largest migration inflow is observed in the Central federal district. Positive indicators of the migration balance were also noted in the North-Western and Southern federal districts. Negative value of the migration balance was revealed in other federal districts. At the same time, the largest outflow of the population was recorded from the Volga and Siberian federal districts. The current situation persists throughout 2017-2018.

The maximum life expectancy observed in the North-Caucasian federal district: 75.86 years in 2017 and 76.25 years in 2018. In the Far Eastern federal district life expectancy is minimal: only just a little higher than 70 years. The average age indicator allows to estimate the age composition in the structure of the labor force and to predict the potential change in the situation in the future. Taking into account that the level of this indicator in the studied regions is closer to the retirement age, it is important to consider lower indicators of the average age as more preferable. The minimum average age was identified in the North Caucasian federal district: 39.5 years in 2017 and 40.2 years in 2018. In the other regions indicator exceeds 40 years. At the same time, the differentiation is relatively small: in the 
Central federal district recorded the highest age (41.6 years in 2017 and 41.9 years in 2018).

The current demographic and migration situation contributes to the formation of trends in the provision of regions with labor potential. Analysis allows to draw a conclusion that the largest share of the labor force with higher and secondary vocational education located in the Central federal district: $84.1 \%$ in $2017-2018$. The minimum value of this indicator was noted in the North-Caucasian federal district: $63.7 \%$ in 2017 and $65.3 \%$ in 2018 . This may indicate the presence of a number of negative factors in the North-Caucasian federal district, including the lack of qualified specialists and the outflow of the educated population to other regions. This factor may also explain minimal average wage level in this region. The maximum share of the employed population from 25 to 65 years with advanced training or professional retraining is observed in the Ural federal district: $35.3 \%$ in 2017 and $38.9 \%$ in 2018 . At the same time, the differentiation of this indicator reaches up to $300 \%$. Thus, the minimal value of this indicator is noted in the North-Caucasian federal district: $12.3 \%$ in 2017 and $13.6 \%$ in 2018 [13. 15].

\section{Conclusions}

The problem of uneven distribution of labor resources in the context of the development of the modern regional economy is a whole complex of factors of influence for the regions that form the labor-deficit depressive territories and the most dynamically developing regions. The intensification of the processes of digitalization reduces the level of dependence between the place of living and work. The pandemic period in the global economy demonstrated different abilities for full online work in a range of professions. If in the past, mostly freelancers in the sphere of information technologies worked remotely, nowadays after the forced transition to online operation, many companies announced plans to continue this practice in the future, because it may save additional money at offices and related costs $[4,7,14]$.

The solution of the problems of the irrational location of the population and labor resources is possible only at the basis of the implementation of a long-term comprehensive program aimed for creating of a common socio-economic environment, which will be characterized by common conditions, especially in the level of wages, which, in turn, is closely related to productivity. In the conditions of the modern regional economy there are several most significant factors that determine the need of growth of labor productivity and development of the social sphere, as well as infrastructure. Migration flows are the result of formation of a fairly large group of population below the poverty line due to the low level of access to high-quality social services.

The research was made as a part of the state task for 2021 (No. 0851-2020-0034) on the topic: "Conceptual foundations for ensuring economic security in the Russian Federation in the context of digitalization: contours of spatial transformations".

\section{References}

1. Baimurzina G.R. and Mirzabalaeva F.I. Index of the effectiveness of the implementation of the employment potential as an indicator of the quality of the social and labour environment (regional aspect). Problems of development of the territory 2(88): 106-123 (2017)

2. Brown W. and Scott D. Human capital location choice: Accounting for amenities and thick labor markets. Journal of Regional Science 52(5): 787-808 (2012) 
3. Fan C. Interprovincial migration, population redistribution, and regional development in China: 1990 and 2000 census comparisons. Professional Geographer 57(2): 295$311(2005)$

4. Kemeny T. and Storper M. The sources of urban development: wages, housing, and amenity gaps across American cities. Journal of Regional Science 52(1): 85-108 (2012)

5. Korzhova G.I. and Suslikova O.A. and Kovarda V.V. and Tsukanova N.E. Manpower of Kursk region as the base of the sustainable development of municipal district asymmetry. SGEM International Multidisciplinary Scientific Conferences: 487-492 (2014)

6. Kovarda V.V. and Shevyakin A.S. The analysis of the manpower of Kursk region as the base of the sustainable development of modern regional economy. In the world of scientific discoveries 10-1(22): 549-559 (2011)

7. Migranova L.A. and Toksanbaeva M.S. Quality of labor potential of the Russian regions. The Population 2(64): 102-120 (2014)

8. Minakova I.V. To the question of increase of efficiency of management of socioeconomic development of the Russian regions. Economy and society 3-2(16): 346-350 (2015)

9. Minakova I.V. and Parkhomchuk M.A. and Golovin A.A. and Bukreeva T.N. Modern economic development: problems and prospects. Proceedings of the 31st International Business Information Management Association Conference: 2975-2981 (2018)

10. Pavlov B.S. Family policy in the region: symbiosis of economic and moral. Journal of economic theory 3: 58-69 (2010)

11. Rijnks R. and Koster S. and McCann P. Spatial heterogeneity in amenity and labor market migration. International Regional Science Review 41(2): 183-209 (2018)

12. Rimashevskaya N.M. and Bochkareva V.K. and Volkova G.N. and Migranova L.A. Quality of labor potential in regions of Russia. The Population 3: 111-138 (2012)

13. Rimashevskaya N.M. and Bochkareva V.K. and Migranova L.A. and Molchanova E.V. and Toksanbaeva M.S. Human potential of Russian regions. The Population 6(61): 084-141 (2013)

14. Schultz T. Investments in the schooling and health of women and men: quantities and return. Journal of Human Resources 28(4): 694-734 (1993)

15. Shevchenko S.V. Evaluation of the effectiveness of the use of labor potential. Proceedings of BSTU. Series 5: Economics and management: 25-29 (2014)

16. Shevyakin A.S. Increasing of efficiency of the demographic policy as a conceptual direction of perfection of the system of reproduction of labor potential. International Scientific Conference "Far East Con" 128: 1823-1827 (2020)

17. Shevyakin A.S. Labor potential of regional economy and factors of it's reproduction. Proceedings of the 32nd International Business Information Management Association Conference: 4886-4888 (2018)

18. Shevyakin A.S. Aspects of change of an ecological situation and their interrelation with condition of labour resources. 3rd International Multidisciplinary Scientific Conference on Social Sciences and Art: 67-72 (2016)

19. Taran P. Globalization and labor migration: the need for a human rights-based policy. The age of globalization 1(5): 66-88 (2010)

20. Zaitseva I.V. and Popova M.V. Demographic development of Stavropol region as a basis of formation of labor resources. Polythematic network electronic scientific journal of Kuban state agrarian University 81: 862-877 (2012)

21. Zaslavskaya T.I. Human potential in the modern transformation process. Social Sciences and modernity 4: 13-23 (2005) 